\title{
Abundance of arthropods as food for meadow bird chicks in response to short- and long-term soil wetting in Dutch dairy grasslands
}

\author{
Livia De Felici ${ }^{\text {Corresp., } 1}$, Theunis Piersma ${ }^{1,2}$, Ruth A. Howison ${ }^{1}$ \\ ${ }^{1}$ Conservation Ecology Group, Groningen Institute for Evolutionary Life Sciences (GELIFES), University of Groningen, Groningen, The Netherlands \\ 2 Department of Coastal Systems and Utrecht University, NIOZ Royal Netherlands Institute for Sea Research, Texel, The Netherlands \\ Corresponding Author: Livia De Felici \\ Email address: de.felici@student.rug.nl
}

Background. Throughout the world, intensive dairy farming has resulted in grasslands almost devoid of arthropods and birds. Meadow birds appear to be especially vulnerable during the chick-rearing period. So far, studies have focused mainly on describing population declines, but solutions to effectively stop these trends on the short-term are lacking. In this study at a single farm, we experimentally manipulated soil moisture through occasional irrigation, to mitigate against early season drainage and create favourable conditions for the emergence of above-ground arthropods during the meadow bird chick rearing phase.

Methods. To guarantee the presence of at least a sizeable arthropod community for the measurement of effects of wetting, we selected a farm with low intensity management. The land use and intensity of the study site and surroundings were categorized according to the national land use database and quantified using remote sensing imagery. From 1 May to 18 June 2017, we compared a control situation, with no water added, to two wetting treatments, a "short-term" (three weeks) treatment based on wetting on warm days with a sprinkler system and a "long-term" treatment next to a water pond with a consistently raised water table from 2010. We measured soil temperature, soil moisture and resistance as well as the biomass of arthropods at three-day intervals. Flying arthropods were sampled by sticky traps and crawling arthropods by pitfall traps. Individual arthropods were identified to Order and their length recorded, to assess their relevance to meadow bird chicks.

Results. The land use analysis confirmed that the selected dairy farm had very low intensity management. This was different from most of the surrounding area ( $20 \mathrm{~km}$ radius), characterized by (very) high intensity land use. The experiments showed that irrigation contributed to cooler soils during midday, and that his happened already in the early part of the season; the differences with the control increased with time. In the short- and long-term treatments, soil moisture increased and soil resistance decreased from the mid-measurement period onward. Compared with the control, cumulative arthropod biomass was higher in the long-term treatment, but showed no change in the irrigation treatment. We conclude that small-scale interventions, such as occasional irrigation, favourably affected local soil properties. However, the effects on above-ground arthropod abundance currently appear limited or overridden by negative landscape-scale processes on arthropods. 
1 Manuscript for PeerJ (dd. 22 Jun 2019):

2

3 Abundance of arthropods as food for meadow bird chicks in

4 response to short- and long-term soil wetting in Dutch dairy

5 grasslands

6 Livia De Felici ${ }^{1}$, Theunis Piersma ${ }^{1,2}$ \& Ruth A. Howison ${ }^{1}$

7

$8 \quad{ }^{1}$ Conservation Ecology Group, Groningen Institute for Evolutionary Life Sciences (GELIFES),

9 University of Groningen, P.O. Box 11103, 9700 CC Groningen, The Netherlands

$10{ }^{2}$ NIOZ Royal Netherlands Institute for Sea Research, Department of Coastal Systems and

11 Utrecht University, P.O. Box 59, 1790AD Den Burg, Texel, The Netherlands

12 Correspondent author:

13 Livia De Felici ${ }^{1}$

14 Nijenborgh 7, 9747AG, Groningen, The Netherlands

15 Email address: liviadefelici@gmail.com 
16 Abstract

17 Background. Throughout the world, intensive dairy farming has resulted in grasslands almost devoid of arthropods and birds. Meadow birds appear to be especially vulnerable during the chick-rearing period. So far, studies have focused mainly on describing population declines, but solutions to effectively stop these trends on the short-term are lacking. In this study at a single farm, we experimentally manipulated soil moisture through occasional irrigation, to mitigate against early season drainage and create favourable conditions for the emergence of aboveground arthropods during the meadow bird chick rearing phase.

Methods. To guarantee the presence of at least a sizeable arthropod community for the measurement of effects of wetting, we selected a farm with low intensity management. The land use and intensity of the study site and surroundings were categorized according to the national land use database and quantified using remote sensing imagery. From 1 May to 18 June 2017, we compared a control situation, with no water added, to two wetting treatments, a "short-term" (three weeks) treatment based on wetting on warm days with a sprinkler system and a "longterm" treatment next to a water pond with a consistently raised water table from 2010 . We measured soil temperature, soil moisture and resistance as well as the biomass of arthropods at three-day intervals. Flying arthropods were sampled by sticky traps and crawling arthropods by pitfall traps. Individual arthropods were identified to Order and their length recorded, to assess their relevance to meadow bird chicks.

Results. The land use analysis confirmed that the selected dairy farm had very low intensity management. This was different from most of the surrounding area (20 km radius), characterized by (very) high intensity land use. The experiments showed that irrigation contributed to cooler 
38 soils during midday, and that his happened already in the early part of the season; the differences

39 with the control increased with time. In the short- and long-term treatments, soil moisture

40 increased and soil resistance decreased from the mid-measurement period onward. Compared

41 with the control, cumulative arthropod biomass was higher in the long-term treatment, but

42 showed no change in the irrigation treatment. We conclude that small-scale interventions, such

43 as occasional irrigation, favourably affected local soil properties. However, the effects on above-

44 ground arthropod abundance currently appear limited or overridden by negative landscape-scale

45 processes on arthropods. 


\section{Introduction}

47 Post-war agricultural intensification of agriculture has negatively altered the ecology of rural

48

49

50

51 landscapes (Newton, 2004, 2017). Herb-rich meadows were replaced by monocultures, foot drains (shallow surface drainage ditches) by underground drainage pipes, while increased grazing pressure and the heavy use of machinery led to the degradation of soil structure and natural soil renewal processes; this resulted in hard dry top soils with low fertility and biodiversity (Roach \& Campbell, 1983; EASAC Secretariat, 2018). These changes were correlated with ongoing declines of arthropods. In German nature reserves, a reduction of 75\% was observed between 1989 and 2017 (Hallmann et al., 2017), probably following a longer trajectory of decline (Benton et al., 2002; Potts et al., 2010). Vegetation homogeneity has implicated the loss of habitat for many arthropod species, while the excessive use of agrochemicals contributed substantially to the disappearance of pollinators and other insects as well (Biesmeijer, 2006; Goulson et al. 2015; Nilsson, Franzén, \& Jönsson, 2008; Ollerton \& Crockett, 2015; Vickery et al., 2001).

Arthropods are integral to healthy terrestrial ecosystem functioning (Seastedt \& Crossley, 1984; Yang \& Gratton 2014). Pollinators are responsible for the sexual reproduction of the majority of flowering plants (Ollerton, Winfree \& Tarrant 2011). About one third of global food production comes from crops that are partially or totally dependent on animal pollination (Klein et al. 2007). In the soil, arthropods play fundamental roles in the decomposition processes (Mattson \& Addy 1975; Chapman et al., 2003; Panizzi \& Parra 2012), influencing nutrient cycles directly and indirectly (Chapman et al., 2003; Hawlena \& Schmitz 2010). Last, but not least, arthropods 
67 represent the food source for all those animals who have an insectivorous diet, including about $6860 \%$ of bird species (Morse 1971).

In the last 40 years, declining European farmland bird populations parallel the arthropod population crash, since meadow birds fail to fledge chicks in environments with low densities of invertebrates (Kentie et al., 2016; Loonstra, Verhoeven, \& Piersma, 2018, 2019; Schekkerman \& Beintema, 2007). In The Netherlands, the population of one such European endemic farmland bird, the Black-tailed Godwit (Limosa limosa limosa), has declined by $>70 \%$, with an alarming rate of 6\% per year in recent years (BirdLife International, 2004; Kentie et al., 2016; van Dijk et al., 2010). Similar declines are shown by Eurasian Oystercatcher (Haematopus ostralegus), Northern Lapwing (Vanellus vanellus), Eurasian Curlew (Numenius arquata) and Common Redshank (Tringa totanus) (PECBMS, 2017; van Dijk et al., 2010). As the diet of small chicks is entirely comprised of above-ground arthropods (Kentie et al., 2016; Loonstra, Verhoeven, \& Piersma, 2018; Schekkerman \& Beintema, 2007), the loss of arthropods negatively affects meadow birds particularly during the breeding season. Food availability is generally hampered directly by the degraded conditions of the soil, with hard and dry top layers that limit the ability of the birds to probe into the ground (Gilroy et al., 2008; McCracken \& Tallowin, 2004; Onrust et al., 2019).

Reducing the management intensity of the agricultural fields can improve soil conditions and habitat quality on the long term. Limited input of agrochemicals facilitates the recovery of pollinator species (Frampton et al., 2000; Goulson et al., 2015), while low additions of organic fertilizer and moderate levels of grazing can encourage sward heterogeneity and benefit invertebrate prey (Vickery et al., 2001). However, these changes require changes in policies on a large scale and require a long time to be implemented. The rapid declining rates in arthropods 
90 and birds call for immediate and innovative solutions (see Fuentes-Montemayor, Goulson \&

91 Park, 2011).

92 Soil temperature and moisture are two important factors that influence arthropods presence.

93 Laboratory experiments show that below an optimal range of moisture, the mortality of many

94 arthropods increases (Cho, Rhee, \& Lee, 2000). Field studies in forests and in agricultural

95 environments also recorded a negative effect of drought on various taxa of soil fauna, with

96 Collembola, Diptera and other predatory arthropods declining under conditions of dry soil and

97 high temperatures (Frampton et al., 2000; Pflug and Wolters, 2001; Lindberg et al., 2002;

98 Tsiafouli et al., 2005). Artificial irrigation can modify soil characteristics and, in some cases,

99 increase the abundance of soil fauna (Frampton et al., 2000; Lindberg et al., 2002). Irrigation is

100 relatively easy for land managers to implement at the individual field scale, which when applied

101 to multiple fields at once, may form the basis for a large-scale management intervention towards

102 improving soil conditions for arthropods and concomitantly meadow birds. However, little is

103 known about the efficacy of short-term irrigation in increasing above-ground arthropods during

104 the breeding season.

105 In this study we manipulated wetting conditions in Dutch dairy grassland. To maximise the

106 possibility of encountering a healthy arthropod community, and therefore maximizing the chance

107 for a positive experimental effect, we chose a conventional agricultural dairy farm with low

108 intensity management (Onrust \& Piersma, 2017). To verify the actual ecological quality of the

109 habitat, we quantified the land use intensity of the farm and its surrounding using remote sensing

110 data (Howison et al., 2018) and information about land use available in the Dutch national

111 database (Ministerie van Economische Zaken en Klimaat, 2018). The farm already adopted

112 measures to promote habitat for breeding meadow birds, including the construction of a water

Peer] reviewing PDF | (2019:02:34775:3:1:NEW 2 Jul 2019) 
113 pond in one of the fields. Therefore, we measured soil conditions (temperature, moisture and

114 resistance) and arthropod biomass under different treatments: a stable high water table in the

115 field that was next to the pond (long-term treatment), and periodical irrigation (short-term

116 treatment) and non-irrigation (control) in an adjacent field. We expected wet and soft soil to offer

117 the best condition for above-ground arthropod community. Therefore, we considered the field

118 with the high water table as the one with the best habitat quality and predicted improvements in

119 soil conditions and arthropod biomass in the irrigated treatment.

121 Materials and Methods

\section{Study site}

123 The experimental study took place at the dairy farm in Wommels, province of Friesland, The

124 Netherlands (N535'35”, E 5’33'51”) (Fig. S1). Authorization to work on this area was granted

125 by the land owner, Murk Nijdam and the Cooperative Verening Sùdewestkust. Land use on this

126 farm has been classified as permanent agricultural grassland since at least 2009 (Ministerie van

127 Economische Zaken en Klimaat, 2018) and was managed for the protection of breeding meadow

128 birds within the Dutch Agri-Environmental Schemes. The management of the grasslands

129 includes one fertilization per year with farmyard manure: a mixture of straw, cattle dung and

130 urine collected and composted for up to a year (Onrust \& Piersma, 2017). Mowing of all

131 meadows takes place after 15 June, because it is assumed that the majority of meadow bird

132 chicks has fledged after this date. The mowing is followed by a period of grazing that continues

133 until October or November. Water is drained by an underground system of pipes, while foot- 
134 drains are absent. All the grasslands of the farm have clay soils. Between May and June

135 temperatures usually range from a minimum of $9-12^{\circ} \mathrm{C}$ to a maximum of $16-18^{\circ} \mathrm{C}$ and the

136 average precipitation is $17.2 \mathrm{~mm}$ (KNMI daggegevens, 1990-2018). The construction in one of

137 the fields of a water pond of approximately 90x50m began in 2009 and finished in 2010.

\section{Contextualization of the landscape}

In order to determine the ecological quality of the surrounding landscape, we analysed the spatial footprint of different land use intensities at increasing buffer distances from the study farm $(2,5$, 10 and $20 \mathrm{~km}$ with the proposed study site as the central point). Land use was categorized with the Dutch national land use database (Ministerie van Economische Zaken en Klimaat, 2018) over four buffer zone distances. Land use intensity, referring to the amount of disturbance, was quantified using the variation surface roughness measured by the Sentinel-1 C-SAR (active radar) satellite and verified with detailed ground surveys (see Howison et al. 2018 for a detailed 147 description).

\section{Wetting experiment}

Two herb-rich meadows of respectively 2.8 ha and 5.4 ha were chosen. In the first grassland an irrigation pipe with six sprinklers was installed. The pipe crossed the land diagonally, from the northwest to the southeast corner (Fig. S1). The sprinklers were placed within $50 \mathrm{~m}$ from each other and had a reach of $12 \mathrm{~m}$. The pipe was connected to a pump that drained water from an adjacent canal. The system was manually activated when the farmer expected a warm day and it 
155 was on for a minimum of 5 min to a maximum of 70 min (Fig. S2). The short-term meadow was

156 divided into four blocks, two irrigated (short-term) and two non-irrigated (control). Each block

157 contained two replicates for the measurements of soil temperature and arthropod abundance,

158 placed $15 \mathrm{~m}$ from each other. The second grassland, with the water pond, was located $100 \mathrm{~m}$

159 south-west from the meadow with the short-term experiments. A set of two replicates was placed

160 in this grassland at equivalent distances $(\sim 35 \mathrm{~m})$ from the pond and the field margin.

\section{Vegetation and soil parameters}

163 One $50 \mathrm{~m}$ transect was laid out perpendicular to the irrigation pipe to account for both the

164 irrigation treatment effect closest to the pipe (distance $0-12 \mathrm{~m}$ ), and the control treatment

165 beyond the reach of the irrigation pipe (distance $20-50 \mathrm{~m}$ ). In the field near water (long-term

166 treatment) a $50 \mathrm{~m}$ transect was laid out $25 \mathrm{~m}$ from the edges of the field to avoid any edge effects

167 and orientated in the same direction as the field with control and irrigation treatment. Vegetation

168 height $( \pm 1 \mathrm{~cm})$ was measured at $1 \mathrm{~m}$ intervals along the transects by lowering a $1 \mathrm{~m}$ vertical

169 measuring rod into the vegetation to the soil surface and drawing the 10 closest leaves their full

170 vertical height. Plant species touching the rod at each $1 \mathrm{~m}$ interval were identified (Streeter et al., 171 2009).

172 Soil temperature was measured by Thermochron ${ }^{\circledR}$ iButton ${ }^{\circledR}$ devices (DS1921G) located at each 173 replicate, sealed into small plastic bags and attached to the surface of the soil. The loggers were

174 programmed to record the temperature every hour starting from the 0.00 on 1 May 2017 until the 175 end of the experiment at 0.00 on 19 June 2017. 
176 Soil moisture was measured at $1 \mathrm{~m}$ intervals along the transects using a ML3 Theta probe (ML3-

177 UM-1.0, EijkelkampAgrisearch Equipment), with settings: device = ML2 and soil type =

178 organic. To account for the full range of well-drained to water-logged soils, field capacity was

179 set to $0.999 \mathrm{~m}-3$.

180 Soil penetration was measured at $1 \mathrm{~m}$ intervals along the transects using a hand-penetrometer for 181 top-layers, (Type IB, EijkelkampAgrisearch Equipment). The internal springs used were 100N, $182 \varnothing 1.6 \mathrm{~mm}$ for soft moist soils and $150 \mathrm{~N}, \varnothing 1.75 \mathrm{~mm}$ for dry hard soil. The force used to push a $1830.25 \mathrm{~cm}^{2}$ cone to a depth of $11 \mathrm{~cm}$ into the soil (the depth important both for emerging 184 arthropods and probing meadow birds (Lourenço et al., 2010) was calculated as: Resistance $185\left(\mathrm{~N} / \mathrm{cm}^{2}\right)=($ total force $(\mathrm{cm}) \times$ spring force $(\mathrm{N} / \mathrm{cm})) /$ cone diameter $\left(\mathrm{cm}^{2}\right)$, thereafter converted with a constant factor to $\mathrm{kg} \cdot \mathrm{cm}^{-2}$. Soil moisture, soil penetration pressure, vegetation composition and height were surveyed at three moments during the season, i.e. early (1 May), midterm (17 May) and late (8 June 2017) (Fig. S2).

\section{Arthropods}

Arthropods were sampled over intervals of three days between 1 May and 18 June, after this date the meadows were mowed. The experiment was stopped as the mowing disrupts any season-long monitoring of arthropod biomass and confounds the eventual effects of the wetting experiment. Sticky traps were used to collect flying arthropods. The traps consisted of yellow plastic boards of 10 by $60 \mathrm{~cm}$ coated in a thin layer of non-drying glue (Bug Scan ${ }^{\circledR}$, Biobest Group NV). In each replicate, the sticky boards were positioned facing a north-south orientation. All the arthropods on the traps were identified to Order and their lengths measured to the nearest mm. 
198 Pitfall traps were used to collect crawling arthropods. They consisted of transparent plastic

199 containers $(300 \mathrm{ml})$ buried into the ground with the rim on the surface. The containers were half

200 filled with a mixture of ethylene glycol and water (1:4) and were refilled approximately once a

201 week to prevent complete evaporation or excessive dilution in case of rain. Arthropod biomasses

202 were calculated using the length-weight equations from Roger et al., 1977 (Rogers, Buschbom,

$203 \&$ Watson, 1977).

\section{Data analysis}

Variation in soil temperatures during the day were analysed using a Generalized Additive Model (GAM) with a normal distribution from the R package mgcv (Wood, 2011). The dataset was divided into two periods: early season (1 May- 16 May 2017) and late season (17 May- 8 June 2017) and analysed separately for days with and without irrigation events. Temperature was used as a response variable, while the treatments and date were used as predictors. Differences in soil moisture, soil resistance and vegetation height among the treatments were investigated using one-way ANOVA, post hoc group contrasts were analysed using Tukey's HSD from the R package Agricolae (de Mendiburu, 2013) with 95\% confidence intervals. Soil moisture was

214 regressed against soil resistance using a linear exponential model.

215 The yields of sticky traps and pitfall traps were analysed separately. Treatment effects on the 216 variation in arthropod biomass during the season were analysed for each Order separately, 217 considering only Orders that represented at least $1 \%$ of the cumulative biomass. Generalized Additive Models (GAM) with $\gamma$ distribution were used to analyse arthropods biomass (the accumulation of arthropods over three-day intervals), with date and treatment as predictor 
220 variables (Zuur et al., 2009). To account for the difference in sample size between treatments,

221 cumulative biomass was calculated for the duration of the experiment; differences between

222 treatments were compared using effect size ratios (Hedges, Gurevitch, \& Curtis, 1999). To

223 analyse the composition in size, the biomass was divided into three length classes: big ( $\geq 4 \mathrm{~mm})$,

224 small $(2-3 \mathrm{~mm})$ and very small arthropods $(1 \mathrm{~mm})$. Land use intensity, categorized into different

225 land use types (Ministerie van Economische Zaken en Klimaat, 2018), was analysed with one-

226 way ANOVA for each buffer distance, and post hoc Tukey HSD was used to determine

227 significantly different groups (de Mendiburu, 2017). All analyses were performed using R 3.3.1

228 (R core team, 2017).

229

230 Results

\section{Contextualization of the landscape}

232 Land use categories showed variation in land use intensity (represented by variation in C-SAR1:

233 Fig. 1), with the lowest intensity use in protected areas and semi-natural grasslands, followed by

234 agricultural grasslands and temporary grasslands and highest intensity use in the arable land.

235 Land use intensity of the categories differed significantly in each buffer zone: $2 \mathrm{~km}$ (ANOVA:

$\left.236 \mathrm{~F}_{(3,473)}=23.4, \mathrm{R}^{2}=0.12, \mathrm{P}<0.001\right), 5 \mathrm{~km}\left(\right.$ ANOVA: $\left.\mathrm{F}_{(3,2368)}=13, \mathrm{R}^{2}=0.01, \mathrm{P}<0.001\right), 10 \mathrm{~km}$

237 (ANOVA: $\left._{(4,8897)}=269.5, \mathrm{R}^{2}=0.10, \mathrm{P}<0.001\right)$, and $20 \mathrm{~km}$ buffer zones (ANOVA: $\mathrm{F}_{(4,21953)}$

$238=1301, \mathrm{R}^{2}=0.19, \mathrm{P}<0.001$ ) (Fig. 1A). The land use intensity of the study farm, characterized as

239 agricultural grassland (Fig. 1A), but scored lower than that of the protected areas (Fig. 1B). 
240 In the immediate proximity ( $2 \mathrm{~km}$ buffer) of the study farm $50 \%$ of the land is under

241 intermediate or high intensity management, which increases to $60 \%$ within a radius of $20 \mathrm{~km}$

242 from the farm (Figs. 2A and B).

\section{Soil parameters}

Between $13.00 \mathrm{~h}$ and $15.00 \mathrm{~h}$, soil temperatures daily reached peaks in all treatments (Fig. 3A and $\mathrm{B})$. During the days with irrigation $(\mathrm{N}=4)$, in the early season the highest values were reached in the control treatment $\left(26.1 \pm 0.8^{\circ} \mathrm{C}\right)($ Fig. $3 \mathrm{~A})$, while in the short-term and long-term treatments the maxima were lower (short-term: $24.3 \pm 0.7^{\circ} \mathrm{C}$; long-term: $19.5 \pm 0.7^{\circ} \mathrm{C}$ ). The GAM model revealed a significantly different pattern of variation between treatments, especially between the control and the long-term treatments. On dry days without irrigation events $(\mathrm{N}=18)$, the highest temperature was reached again in the control treatment $\left(25.5 \pm 0.5^{\circ} \mathrm{C}\right)$, followed by short-term $\left(24.0 \pm 0.4{ }^{\circ} \mathrm{C}\right)$, and the long-term treatment $\left(19.8 \pm 0.4^{\circ} \mathrm{C}\right)$. In this case, the GAM revealed different patterns of variation, either for the control and the long-term treatment, than for the control and short-term treatment (Table 1). During the late season, temperatures were higher (Fig. 3B). On days with irrigation events $(\mathrm{N}=5)$, the highest values were registered in the control treatment $\left(31.3 \pm 0.5^{\circ} \mathrm{C}\right)$, followed by the short-term treatment $\left(25.1 \pm 0.4^{\circ} \mathrm{C}\right)$ and the long-term one $\left(20.6 \pm 0.3^{\circ} \mathrm{C}\right)$. The variation in temperature over time was significantly different between treatments (Table 1). Similarly, during days without irrigation $(N=7)$ the highest peaks were in the control treatment $\left(32.0 \pm 0.5^{\circ} \mathrm{C}\right)$, followed by the irrigation $(27.5 \pm 0.4)$ and then the long-term treatment $\left(21.0 \pm 0.3^{\circ} \mathrm{C}\right)$. In this case as well, the variation in temperature over time 261 was significantly different between treatments (Table 1). 
262 In all three treatments, soil moisture decreased during the season (Fig. 4A). During the first

263 survey on1 May the highest moisture level was recorded in the short-term treatment $(46.5 \pm$

$2644.9 \%)$, followed by the long-term one $(43.2 \pm 5.6 \%)$, while the control treatment was

265 significantly dryer $(36.7 \pm 4.92 \%)\left(\right.$ ANOVA: $\left.\mathrm{F}_{(2,90)}=20.6, \mathrm{R}^{2}=0.31, \mathrm{P}<0.001\right)$. During the

266 second survey, the short-term site kept the highest moisture values $(48.3 \pm 5.5 \%)$, followed this

267 time by the control $(35.4 \pm 3.5 \%)$ and finally by the long-term treatment $(33.1 \pm 4.0 \%)$. The mean

268 moisture value was significantly different for each treatment $\left(\right.$ ANOVA: $\mathrm{F}_{(2,90)}=70.8, \mathrm{R}^{2}=0.61$,

$269 \mathrm{P}<0.001)$. At the third and last survey on 8 June the short-term treatment was still the one with

270 the highest moisture value $(33.8 \pm 8.2 \%)$, but there was no significant difference with the control

271 anymore $(28.3 \pm 4.4 \%)$. The long-term treatment $(28.3 \pm 4.4 \%)$, on the other hand, had a

272 significantly lower level of moisture $\left(\right.$ ANOVA: $\left.\mathrm{F}_{(2,90)}=70.9, \mathrm{R}^{2}=0.15, \mathrm{P}<0.001\right)$.

273 Soil resistance increased in the course of the season in all three treatments (Fig. 4B) (2.8 \pm 0.8

$\left.274 \mathrm{~kg} / \mathrm{cm}^{2}\right)$. During the first survey the highest resistance was recorded in the control treatment $(4.5$

$\left.275 \pm 1.1 \mathrm{~kg} / \mathrm{cm}^{2}\right)$ and was significantly different from the short-term $\left(2.9 \pm 0.7 \mathrm{~kg} / \mathrm{cm}^{2}\right)$ and the

276 long-term treatments $\left(2.8 \pm 0.7 \mathrm{~kg} / \mathrm{cm}^{2}\right)\left(\operatorname{ANOVA}: \mathrm{F}_{(2,90)}=30.7, \mathrm{R}^{2}=0.46, \mathrm{P}<0.001\right)$. During the

277 mid-season survey soil resistance was highest in the control treatment $\left(6.1 \pm 1.6 \mathrm{~kg} / \mathrm{cm}^{2}\right)$,

278 followed by the long-term $\left(3.9 \pm 1.1 \mathrm{~kg} / \mathrm{cm}^{2}\right)$ and the short-term treatments $\left(2.6 \pm 1.1 \mathrm{~kg} / \mathrm{cm}^{2}\right)$

279 (ANOVA: $\mathrm{F}_{(2,90)}=41.7, \mathrm{R}^{2}=0.48, \mathrm{P}<0.001$ ). In the third survey, once again the highest soil

280 resistance was observed in the control treatment $\left(5.8 \pm 1.3 \mathrm{~kg} / \mathrm{cm}^{2}\right)$, followed by the short-term

$281\left(4.5 \pm 1.1 \mathrm{~kg} / \mathrm{cm}^{2}\right)$ and long-term treatments $\left(3.7 \pm 1.0 \mathrm{~kg} / \mathrm{cm}^{2}\right)\left(\right.$ ANOVA: $\mathrm{F}_{(2,90)}=31.8, \mathrm{R}^{2}=$

$2820.41, \mathrm{P}<0.001)$. Soil resistance was correlated with the level of moisture by an inverse proportion

283 relationship (Exponential LM: $\left.\mathrm{F}_{(1,298)}=110, \mathrm{R}^{2}=0.27, \mathrm{P}<0.001\right)$. 
284 Twenty-three different plant species were identified. Species richness was similar in the two 285 transects, but the proportion in which the plants were present was different (Table S1). The 286 short-term grassland presented a predominance of herbaceous species (Taraxacum officinale,

287 Trifolium pratensis, Rumix acetosa, Ranunculus acris), while graminoid species dominated the 288 grassland near water (long-term treatment) (Dactylis glomerata, Alopercus pratensis, Bromus

289 hordaceous, Elytrigia repens, Poa trivialis). Vegetation height increased progressively in all three 290 treatments (Fig. 4C). At the beginning of the season, vegetation was highest in the long-term 291 treatment $(17.3 \pm 5.5 \mathrm{~cm})$, followed by the short-term $(14.9 \pm 9.4 \mathrm{~cm})$ and the control treatments $292(11.7 \pm 5.9 \mathrm{~cm})\left(\right.$ ANOVA: $\left.\mathrm{F}_{(2,90)}=7.7, \mathrm{R}^{2}=0.15, \mathrm{P}<0.001\right)$. In this case only the first and the last 293 one differed significantly. During mid-season there were no significant differences among

294 treatments and the highest vegetation was still found in the long-term treatment $(36.6 \pm 13.9 \mathrm{~cm})$, 295 followed by the control $(31.7 \pm 12.6 \mathrm{~cm})$ and the short-term ones $(29.0 \pm 9.8 \mathrm{~cm})$ (ANOVA:

$\left.296 \mathrm{~F}_{(2,90)}=2.3, \mathrm{R}^{2}=0.05, \mathrm{P}<0.001\right)$.

297 By the end of the season the situation in trend was similar to the beginning, with the long-term 298 treatment being the one with highest vegetation $(57.8 \pm 19.9 \mathrm{~cm})$ followed by the short-term $299(47.2 \pm 19.6 \mathrm{~cm})$ and the control treatments $(44.4 \pm 17.8 \mathrm{~cm})$. As in the beginning of the season, 300 the only significant difference was found between the long-term treatment and the control one $301 \quad\left(\right.$ ANOVA: $\left.\mathrm{F}_{(2,90)}=5.1, \mathrm{R}^{2}=0.10, \mathrm{P}<0.001\right)$.

\section{Arthropod biomass}

304 The main arthropod Orders present in the sticky traps were Diptera $(80.5 \%)$, Lepidoptera 305 (12.4\%), Coleoptera (2.8\%), Hemiptera (2.5\%) and Hymenoptera (1.7\%). Aranaea, Acari and 
306 Collembola were also present, but contributed $<1 \%$ to the total biomass, therefore were not used

307 in further analysis (Table S2).

308 For Diptera, the pattern of variation between sticky trap biomass in the long-term treatment and

309 the control treatment differed significantly (Table 2). Arthropod biomass was generally higher in

310 the long-term treatment than the other two treatments. Diptera biomass peaked on 22 May with

311 mean biomass of $464 \pm 74 \mathrm{mg}$. In the control and short-term treatments the peak was narrower,

312 with the maximum on the same date, but lower biomass immediately before and after (Fig. 5A).

313 For Hemiptera there was a significant difference in the patterns of sticky trap biomass in the

314 long-term treatment compared to the control and short-term ones (Table 2). The main peak in the

315 last two was reached 12-15 June, with a mean biomass of $42 \pm 9 \mathrm{mg}$ in the short-term treatment

316 and $37 \pm 1 \mathrm{mg}$ in the control treatment. In the long-term treatment, flying Hemiptera were

317 consistently low or absent (Fig. 5D).

318 For the other Orders (Lepidoptera, Coleoptera and Hymenoptera) there were no significant

319 differences among treatments in the patterns of variation during the season (Table 2).

320 Lepidoptera appeared mainly in the last part of the season, small peaks were visible in the long-

321 term treatment around the 3 June and in the control treatment around 9 June (Fig. 5B).

322 Coleoptera reached the maximum abundance during the last part of the season, with the highest

323 peaks in the control $(60 \pm 49 \mathrm{mg})$ and in long-term treatments (32 $\pm 24 \mathrm{mg})$ on 18 June (Fig. 5C).

324 Hymenoptera showed a constant, low-abundance pattern during the season, with two shallow

325 peaks in the short-term treatment on the $17(12 \pm 2 \mathrm{mg})$ and 31 May $(8 \pm 2 \mathrm{mg})$ (Fig. 5E). The

326 comparison of treatment effects on cumulative biomass showed no effect of the irrigation

327 treatment and a positive effect of the long-term treatment (Table 3). On average, less than 10\% 
328 of the individuals from each sampling events had a size of $\geq 4 \mathrm{~mm}(8.5 \%, \mathrm{SD}=4.5)$, while the

329 vast majority was small, with a length of 2 or $3 \mathrm{~mm}(43.1 \%, \mathrm{SD}=11.7)$ or very small, with a

330 length of $1 \mathrm{~mm}(48.3 \%, \mathrm{SD}=11.8)$ (Fig. 6$)$.

331 In the pitfall traps, the composition consisted mainly in Coleoptera (40.1\%), Aranaea (33.3\%),

332 Diptera (12.6\%) and Lepidoptera (7.3\%). Samples presented also minor quantity $(<1 \%)$ of

333 Hymenoptera, Coleoptera larvae and Lepidoptera larvae, Hemiptera, Collembola and Acari

334 (Table S2). All the GAM models for the different Orders of the pitfall traps showed the date

335 affecting biomass over the season $(\mathrm{P}<0.001)$, but no difference in the pattern of variation among

336 treatments (Table 4). Coleoptera showed a pattern with a progressive increase by the end of the

337 season, with the highest peak in the control field (111 $\pm 5 \mathrm{mg})$ (Fig. 7A). Aranaea had a small

338 peak in all the treatments during the first half of the season, between 19 and 22 May (control: 57

$339 \pm 1 \mathrm{mg}$, short-term: $46 \pm 9 \mathrm{mg}$, long-term: $66 \pm 3 \mathrm{mg}$ ) (Fig. 7B). Diptera were most abundant in

340 the pitfall traps shortly after the beginning of the season (control: $19 \pm 6 \mathrm{mg}$, short-term: $20 \pm 5$

$341 \mathrm{mg}$, long-term $22 \pm 8 \mathrm{mg}$ ), while showed a constant and low-abundance pattern during the rest of

342 time (Fig. 7C). Lepidoptera showed a constant pattern during the whole season, with no peaks in

343 any particular treatment (Fig. 7D). Compared with the sticky traps, the ratio between cumulative

344 biomass in the short-term and long-term sites against the controls but there was still a small

345 positive effect of the treatments (Table 3 ). The average of arthropods with a size $\geq 4 \mathrm{~mm}$ in each

346 sampling events was higher than in the sticky traps $(31 \%, \mathrm{SD}=12)$.Very small individuals with

347 size of $1 \mathrm{~mm}$ represented almost half of the samples $(49 \%, \mathrm{SD}=14)$, while arthropods with size

$3482-3 \mathrm{~mm}$ constituted the rest $(20 \%, \mathrm{SD}=10)($ Fig. 8). 
350 Discussion

351 The experimental soil wetting was carried out in two fields classified as conventional agricultural

352 grasslands with low land use intensity, in accordance with the intended provision of meadow

353 bird breeding habitat (Onrust \& Piersma, 2017). The strengths of this study are its experimental

354 and comparative character, the detailed observations on soils and arthropods and the novel

355 landscape contextualization. The quantification of land use intensity added a new and valuable

356 dimension to the national land use categories, spatially contextualizing these low intensity

357 managed fields within a neighbourhood of high intensity managed agricultural grasslands. We

358 see this study as a starting point: the fast development of technologies to measure arthropod

359 abundances and diversity with automated image recognition (Martineau et al., 2017), should now

360 make it possible to redo this type of study with adequate replication across farms and across

361 time.

362 Soil temperature, moisture and resistance are key factors in many phases of arthropods life-

363 cycles. The occasional wetting was able to modify characteristics of the soil keeping the soil

364 cool, moist and soft. Irrigation did affect ground temperature already early in the season, with

365 greater differences in temperature peaks as the season proceeded. The addition of water also

366 affected soil moisture, keeping it significantly higher until mid-season, while soil resistance was

367 always lower in the short-term treatment rather than in the control. Hulten \& Clarke (2006)

368 showed that for some Diptera extreme moisture conditions have significant influence on pupal

369 survival, with high mortality in dry soils and less likelihood to penetrate them to pupate. Eggs are

370 vulnerable to desiccation and high temperature can accelerate hatching rates but decrease larval

371 survival (Johnson, 2010). Laboratory studies on different species showed effects on the

372 regulation of the diapauses and the development of the larvae (Cho, Rhee, \& Lee, 2000; Dimou

PeerJ reviewing PDF | (2019:02:34775:3:1:NEW 2 Jul 2019) 
373 et al., 2003; Ellis et al., 2004; Neven, 2000). Thus, the wet conditions created in this study are

374 expected to favour arthropods emergence (Hamza \& Anderson, 2005; Hulthen \& Clarke, 2006;

375 Johnson et al., 2010). Nevertheless, the effect on invertebrate biomass in the short-term treatment

376 was small. Since the irrigation only started at the beginning of the breeding season, it is possible

377 that the beneficial effects of the irrigation on arthropods biomass would only have become

378 evident after the sampling period, when the eggs and larvae that were in the soil during the

379 experiment would have hatched and emerged. In any case, such delayed effects of the irrigation

380 on arthropod biomass would not have benefitted meadow bird chicks, growing up during the

381 short window of time covered by our sprinkler treatment (Kentie et al., 2018; Loonstra et al.,

382 2018). We note that the vast majority of the arthropods was either small (2-3 $\mathrm{mm})$ or very small

383 (1 mm). The pitfall traps had higher proportion of bigger individuals $(\geq 4 \mathrm{~mm})$ than the sticky

384 traps, although the cumulative biomass in these traps was remarkably lower. According to

385 Beintema et al. (1991), arthropods of this size would not be large enough to sustain growing

386 meadow bird chicks.

387 The overall conditions of lower temperatures, elevated initial moisture and soft soil were

388 associated with a higher cumulative arthropod biomass in the long-term treatment. This is

389 consistent with the idea that stable wet conditions promote egg-laying opportunities for

390 arthropods. As soil temperatures were consistently lower than in the control and short-term

391 wetting treatments, the stable high water table would have provided a buffer to temperature

392 fluctuations, keeping the soil cooler throughout the day. These may have been beneficial for the

393 soil fauna, as heat peaks like those recorded in the control and short-term treatments may

394 negatively affect arthropod larvae and adult survival (Gilbert \& Raworth, 1996; Neven, 2000). 
395 Plant communities shape arthropod communities (Perner et al., 2005; however, see Schaffers et

396 al., 2008), so differences in vegetation might have contributed to the differences between fields

397 where the experiment was conducted. Differences in plant species composition might also be

398 behind the uneven presence of the Hemiptera, that were completely absent in the long-term

399 treatment. Almost all the individuals sampled from this Order were leafhoppers (Cicadellidae)

400 and the distribution of these plant-sucking insects is tightly related to presence of the host plant

401 species (Biederman, 2002). The proximity to a pond in the long-term treatment might have

402 contributed to the abundance of flying arthropods, who came close to the water for feeding or

403 courtship (Fig 5) (Drake, 2001).

404 The landscape analysis revealed that the management intensity of the dairy farm where the study

405 took place is even lower than in protected areas (Fig 1B). Therefore, the study farm should yield

406 good chances of finding a healthy invertebrate community. However, the farm is embedded in a

407 landscape with high intensity use. In fact, the analysis revealed that half of the fields in the

408 surroundings of the farm have intermediate or high intensity of usage, and the percentage of high

409 intensity use increases with distance. Furthermore, the data on land use classification indicates

410 that some of the low intensity fields that are present are monocultures and therefore with very

411 limited diversity. Local factors, such as management practices, and regional factors, such as

412 distance to high-diversity habitats, determine local biodiversity (Tscharntke \& Brandl, 2004). It

413 seems likely that the effects of the wetting were limited or overridden by negative landscape-

414 scale processes.

415 While current studies meticulously document and call attention to the alarming loss of

416 biodiversity from the 1950s (Lister \& Garcia, 2018; Newton, 2017; WWF, 2018), innovative

417 short-term management actions are needed to mitigate against the ongoing trajectory of decline.

PeerJ reviewing PDF | (2019:02:34775:3:1:NEW 2 Jul 2019) 
418 The wetting experiments showed how important moisture is to improve soil conditions.

419 Nevertheless, the restoration of biodiversity-rich agricultural landscapes requires landscape-wide

420 changes in agriculture.

421

\section{Conclusions}

423 We hypothesized that the occasional irrigation in a dairy farm would improve soil conditions and

424 enhance arthropod emergence during the period of rapid growth by meadow bird chicks. The 425 landscape analysis confirmed that the experimental farm had low levels of land use and a good

426 chance to offer a relatively healthy invertebrate community. We found that the (long-term)

427 treatment of stable high water provided more arthropod biomass to prospective young meadow

428 birds than short-term water irrigated and control fields. Irrigation made soils cooler, moister and

429 softer, but on the short term the arthropod biomass did not visibly respond. Moreover, and 430 perhaps reflecting the wider landscape context, the arthropods sampled were generally too small

431 to be considered suitable food for meadow bird chicks. Thus, we emphasize the urgency of

432 finding innovative solutions to stop biodiversity loss in agricultural environments on the short433 and the long-term.

\section{Acknowledgements}

436 We thank farmer Murk Nijdam for his ideas to enable this test of some of his ideas on the 437 availability of arthropods for meadow bird chicks and for facilitating and carrying out the actual 
438 wetting experiment. We are grateful for the encouragement and feedback by Jouke Altenburg 439 and we thank the anonymous reviewers for constructive comments. 


\section{References}

442 Beintema, A. J., Thissen, J. B., Tensen, D., \& Visser, G. H. (1991). Feeding ecology of

443 Charadriiform chicks in agricultural grassland. Ardea, 79, 31-43.

444 Benton, T. G., Cole, L. J., Benton, T. I. M. G., Bryant, D. M., Cole, L., \& Crick, H. Q. P. (2002).

445 Linking agricultural practice to insect and bird populations: a historical study over three decades.

446 Journal of Applied Ecology, 39, 673-687.

447 Biederman, R. (2002). Leafhoppers (Hemiptera, Auchenorrhyncha) in fragmented habitats.

448 Denisia, 176, 523-530.

449 Biesmeijer, J. C. (2006). Parallel declines in pollinators and insect-pollinated plants in Britain

450 and The Netherlands. Science, 313, 351-354.

451 BirdLife International. (2004). Birds in Europe: population estimates, trends and conservation

452 status. Cambridge, UK: BirdLife International Series No. 12.

453 Chapman, S. K., S. C. Hart, N. S. Cobb, T. G. Whitham, and G.W. Koch. (2003). Insect

454 herbivory increases litter quality and decomposition: an extension of the acceleration hypothesis.

455 Ecology, 84, 2867-2876

456 Cho, Y., Rhee, S., \& Lee, S. (2000). Effect of soil moisture on development. Florida

457 Entomologist, 3, 915-919.

458 de Mendiburu F. (2013). Statistical procedures for agricultural research. Package 'Agricolae,'

459 version 1.4-4. Comprehensive R Archive Network, Institute for Statistics and Mathematics,

460 Vienna, Austria.

461 Dimou, I., Koutsikopoulos, C., Economopoulos, A. P., \& Lykakis, J. (2003). Depth of pupation

462 of the wild olive fruit fly, Bactrocera (Dacus) oleae (Gmel.) (Dipt., Tephritidae), as affected by

463 soil abiotic factors. Journal of Applied Entomology, 127, 12-17.

464 Drake, M. (2001). The importance of temporary waters for Diptera (true-flies). Freshwater

465 Forum, 17, 26-39. 
466 Ellis, J. D., Hepburn, R., Luckman, B., \& Elzen, P. J. (2004). Effects of soil type, moisture, and 467 density on pupation success of Aethina tumida (Coleoptera: Nitidulidae). Environmental 468 Entomology, 33, 794-798.

469 EASAC Secretariat (2018). Opportunities for soil sustainability in Europe. Teutschenthal, 470 Germany: Deutsche Akademie der Naturforscher Leopoldina.

471 Frampton, G.K., van den Brink, P.J., Gould, P.J.L., (2000). Effects of spring drought and 472 irrigation on farmland arthropods in southern Britain. Journal of Applied. Ecology. 37, 865-883.

473 Fuentes-Montemayor, E., Goulson, D., \& Park, K. J. (2011). The effectiveness of agri-

474 environment schemes for the conservation of farmland moths: Assessing the importance of a 475 landscape-scale management approach. Journal of Applied Ecology, 48, 532-542.

476 Gilbert, N., \& Raworth, D. A. (1996). Insects and temperature- a general theory. The Canadian 477 Entomologist, 128, 1-13

478 Gilroy, J. J., Anderson, G. Q. A., Grice, P. V., Vickery, J. A., Bray, I., Nicholas Watts, P., \& 479 Sutherland, W. J. (2008). Could soil degradation contribute to farmland bird declines? Links 480 between soil penetrability and the abundance of Yellow wagtails Motacilla flava in arable fields. 481 Biological Conservation, 141, 3116-3126.

482 Goulson, D., Nicholls, E., Botías, C., \& Rotheray, E. L. (2015). Bee declines driven by combined 483 stress from parasites, pesticides, and lack of flowers. Science, 347, 1435-1444.

484 Groen, N. M., Kentie, R., Goeij, P. de, Verheijen, B., Hooijmeijer, J. C. E. W., \& Piersma, T. 485 (2012). A modern landscape ecology of Black-tailed Godwits: habitat selection in southwest 486 Friesland, The Netherlands. Ardea, 100, 19-28.

487 Hallmann, C. A., Sorg, M., Jongejans, E., Siepel, H., Hofland, N., Schwan, H., de Kroon, H. 488 (2017). More than 75 percent decline over 27 years in total flying insect biomass in protected 489 areas. PLoS ONE, 12, 1-21.

490 Hamza, M. A., \& Anderson, W. K. (2005). Soil compaction in cropping systems: A review of the 491 nature, causes and possible solutions. Soil and Tillage Research, 82, 121-145. 
492 Hawlena, D., \& Schmitz O. J. (2010). Herbivore physiological response to fear of predation 493 alters ecosystem nutrient dynamics. Proceedings of the National Academy of Sciences USA 107, 494 15503-15507.

495 Hedges, L. V, Gurevitch, J., \& Curtis, P. S. (1999). The meta-analysis of response ratios in 496 experimental ecology. Ecology, 80, 1150-1156.

497 Howison, R. A., Piersma, T., Kentie, R., Hooijmeijer, J. C. E. W., \& Olff, H. (2018).

498 Quantifying landscape-level land- use intensity patterns through radar- based remote sensing, 499 Journal of Applied Ecology, 55,1276-1287.

500 Hulthen, A. D., \& Clarke, A. R. (2006). The influence of soil type and moisture on pupal 501 survival of Bactrocera tryoni (Froggatt) (Diptera: Tephritidae). Australian Journal of 502 Entomology, 45, 16-19.

503 Johnson, S. N., Gregory, P. J., McNicol, J. W., Oodally, Y., Zhang, X., \& Murray, P. J. (2010).

504 Effects of soil conditions and drought on egg hatching and larval survival of the clover root 505 weevil (Sitona lepidus). Applied Soil Ecology, 44, 75-79.

506 Kentie, R., Senner, N. R., Hooijmeijer, J. C. E. W., Márquez-, R., Figuerola, J., Masero, J. A., 507 Hooijmeijer, J. C. E. W. (2016). Estimating the size of the Dutch breeding population of 508 continental Black-tailed Godwits from 2007- 2015 using resighting data from spring staging 509 sites. Ardea, 104, 213-225.

510 Kentie, R., Coulson, T., Hooijmeijer, J.C.E.W., Howison, R.A., Loonstra, A.H.J., Verhoeven, 511 M.A., Both, C. \& Piersma, T. (2018). Warming springs and habitat alteration interact to impact 512 timing of breeding and population dynamics in a migratory bird. Global Change Biology, 24, $513 \quad 5292-5303$.

514 Klein, A.M., Vaissiere, B. E, Cane, J. H, Steffan-Dewenter, I., Cunningham, S. A, Kremen, C., 515 Tscharntke, T. (2007). Importance of pollinators in changing landscapes for world crops.

516 Proceedings of the Royal Society of London B, 274, 303-313 
517 Lindberg, N., Bengtsson, J.B., Persson, T. (2002). Effects of experimental irrigation and drought 518 on the composition and diversity of soil fauna in a coniferous stand. Journal of Applied Ecology $51939,924-936$.

520 Lister, B. C., \& Garcia, A. (2018). Climate-driven declines in arthropod abundance restructure a 521 rainforest food web, Proceedings of the National Academy of Science USA, 115, 10397-10406.

522 Loonstra, A. H. J., Verhoeven, A. M., \& Piersma, T. (2018). Sex-specific growth in chicks of the 523 sexually dimorphic Black-tailed Godwit. Ibis, 160, 89-100.

524 Loonstra A.H.J., Verhoeven, M.A, Senner, N.R., Hooijmeijer, J.C.E.W., Piersma, T., Kentie R. 525 (2019). Natal habitat and sex-specific survival rates result in a male-biased adult sex ratio. 526 Behavioral Ecology. arz021.

527 Mace, G. M., Barrett, M., Burgess, N. D., Cornell, S. E., Freeman, R., Grooten, M., \& Purvis, A. 528 (2018). Aiming higher to bend the curve of biodiversity loss. Nature Sustainability, 1, 448-451.

529 Maxime Martineau, Donatello Conte, Romain Raveaux, Ingrid Arnault, Damien Munier, Gilles 530 Venturini (2017). A Survey on image-based insect classification. Pattern Recognition, Elsevier, $53165,273-284$.

532 Mattson, W. \& Addy N. D. (1975). Phytophagous insects as regulators of forest primary 533 production. Science, 190, 515-522.

534 McCracken, D. I., \& Tallowin, J. R. (2004). Swards and structure: the interactions between 535 farming practices and bird food resources in lowland grasslands. Ibis, 146, 108-114.

536 Ministerie van Economische Zaken en Klimaat. (2018). Basisregistratie Gewaspercelen (BRP).

537 Morse, D. N. (1971). The insectivorous bird as an adaptive strategy. Annual Review of Ecology 538 and Systematic 2, 177-200

539 Neven, L. G. (2000). Physiological responses of insects to heat. Postharvest Biology and 540 Technology, 21, 103-111.

541 Newton, I. (2004). The recent declines of farmland bird populations in Britian: an appraisal of 542 causal factors and conservation actions. Ibis, 146, 579-600. 
543 Newton, I. (2017). Farming and birds. London: Harper Collins.

544 Nilsson, S. G., Franzén, M., \& Jönsson, E. (2008). Long-term land-use changes and extinction of 545 specialised butterflies. Insect Conservation and Diversity, 1,197-207.

546 Ollerton, J., \& Crockett, R. (2015). Extinctions of aculeate pollinators and the role of large-scale 547 agricultural changes. Science, 346, 1360-1363.

548 Ollerton, J., Winfree, R., Tarrant, S. (2011). How many flowering plants are pollinated by 549 animals? Oikos, 120, 321-326.

550 Onrust, J., \& Piersma, T. (2017). The hungry worm feeds the bird. Ardea, 105, 153-161.

551 Onrust, J., Wymenga, E., Piersma, T., Olff, H. (2019). Earthworm activity and availability for 552 meadow birds is restricted in intensively managed grasslands. Journal of Applied Ecology. 00, 553 1-10. https://doi.org/10.1111/1365-2664.13356

554 Panizzi, A. R., \& Parra J. R. (2012). Insect Bioecology and Nutrition for Integrated Pest 555 Management. CRC Press, Boca Raton, FL.

556 PECBMS. (2017). Trends and indicators: European indicators. Retrieved from: https://

557 pecbms.info/trends-and-indicators/indicators/all/yes/indicators/E_C_All,E_C_Fa/ [accessed 27 558 January 2019]

559 Perner, J., Wytrykush, C., Kahmen, A., Buchmann, N., Egerer, I., Creutzburg, S., Odat, N., 560 Audorff, V. and Weisser, W. W. (2005), Effects of plant diversity, plant productivity and habitat 561 parameters on arthropod abundance in montane European grasslands. Ecography, 28, 429-442.

562 Pflug, A., Wolters, V. (2001). Influence of drought and litter age on Collembola communities. 563 European Journal of Soil Biology. 37, 305-308.

564 Potts, S. G., Biesmeijer, J. C., Kremen, C., Neumann, P., Schweiger, O., \& Kunin, W. E. (2010). 565 Global pollinator declines: Trends, impacts and drivers. Trends in Ecology and Evolution, 25, $566345-353$.

567 R core team. (2017). CRAN R version 3.3.1. 
568 Roach, S. H., \& Campbell, R. B. (1983). Effects of soil compaction on Bollworm (Lepidoptera:

569 Noctulidae) Moth emergence. Environmental Entomology, 12. 1882-1885

570 Rogers, L. E., Buschbom, R. L., \& Watson, C. R. (1977). Length-Weight Relationships of

571 Shrub-Steppe Invertebrates 1. Annals of the Entomological Society of America, 70, 51-53.

572 Schekkerman, H., \& Beintema, A. J. (2007). Abundance of invertebrates and foraging success of

573 Black-tailed Godwit Limosa limosa chicks in relation to agricultural grassland management.

574 Ardea, 95, 39-54.

575 Schaffers, A. P., Raemakers, I. P., Sýkora, K. V. \& ter Braak, C. J. (2008).Arthropod

576 assemblages are best predicted by plant species composition. Ecology, 89, 782-794.

577 Seastedt, T.R. \& Crossley, D.A. Jr (1984) The influence of arthropods on ecosystems.

578 Bioscience, 34, 157-161.

579 Streeter, D., Hart-Davies, C., Hardcastle, A., Cole, F., \& Harper, L. (2009). Collins flower guide.

580 The most complete guide to the flowers of Britain and Europe. London: Collins.

581 Tauber, M. J., Tauber, C. A., Nyrop, J. P., \& Villani, M. G. (1998). Moisture, a vital but

582 neglected factor in the seasonal ecology of insects: hypotheses and tests of mechanisms.

583 Environmental Entomology, 27, 523-530.

584 Tscharntke, T., \& Brandl, R. (2004). Plant-insect interactions in fragmented landscapes. Annual 585 Review of Entomology, 49, 405-430.

586 Tsiafouli, M. A., Kallimanis, A. S., Katana, E., Stamou, G. P., \& Sgardelis, S. P. (2005).

587 Responses of soil microarthropods to experimental short-term manipulations of soil moisture.

588 Applied Soil Ecology, 29, 17-26.

589 van Dijk, A. J., Boele, A. J., Hustings, F., Koffijberg, K., \& Plate, C. L. (2010). Broedvogels in

590 Nederland in 2008. Beek-Ubbergen: SOVON Vogelonderzoek Nederland.

591 Vickery, J. A., Tallowin, J. R., Feber, R. E., Asteraki, E. J., Atkinson, P. W., Fuller, R. J., \&

592 Brown, V. K. (2001). The management of lowland neutral grasslands in Britain: effects of 
593 agricultural practices on birds and their food resources. Journal of Applied Ecology, 38, 647594664.

595 Wood, S. N. (2011). Fast stable restricted maximum likelihood and marginal likelihood 596 estimation of semiparametric generalized linear models. Journal of the Royal Statistical 597 SocietyB, 73, 3-36.

598 WWF. (2018). Living Planet Report - 2018: Aiming Higher. Grooten, M. and Almond, R.E.A. 599 (Eds). WWF, Gland, Switzerland.

600 Yang, L. H., and Gratton, C. (2014). Insects as drivers of ecosystem processes. Current Opinion 601 in Insect Science, 2, 26-32.

602 Zuur, A. F., Ieno, E. N., Walker, N., Saveliev, A. A., \& Smith, G. M. (2009). Mixed effects 603 models and extensions in ecology with R. R. Springer Science Business Media, LLC. 


\section{Figure 1}

Classification of land use and land use intensity variation

Image created using data from Basisregistratie Gewaspercelen (BRP); (A) Agricultural land use was divided into buffer distances of 2, 5, 10 and $20 \mathrm{~km}$ surrounding the study farm and categorized as different land use types; (B) Variation in land use intensity was classified into different land use types (colour codes in A and B are identical). The horizontal line represents the average land use intensity of our study site \pm SD. Different letters represent significant differences $\mathrm{P}<0.05$ (Tukey HSD), within buffer distances. 

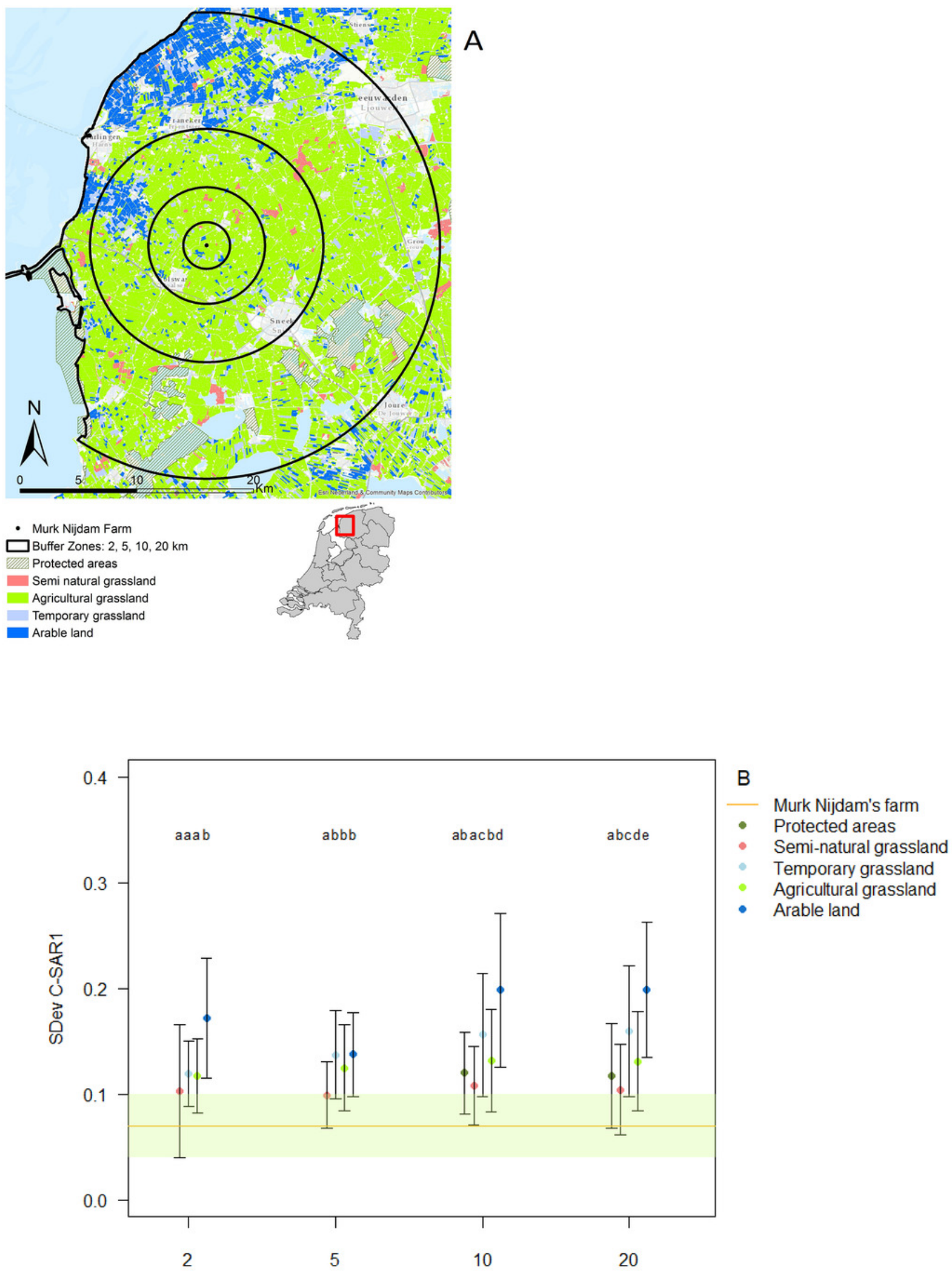

Buffer (km) 


\section{Figure 2}

\section{Agricultural land use intensity}

Agricultural land use intensity divided into buffer distances of 2, 5, 10 and $20 \mathrm{~km}$ surrounding the study farm, summarized as (A) the standard deviation of change in Radar derived surface roughness (SDev CSAR1); (B) Proportion of land under different land use intensities within agricultural fields surrounding the study farm.

Imagine produced with the data from ESA remote sensing data, sentinel 1 CSAR and processed by Ruth A. Howison, University of Groningen

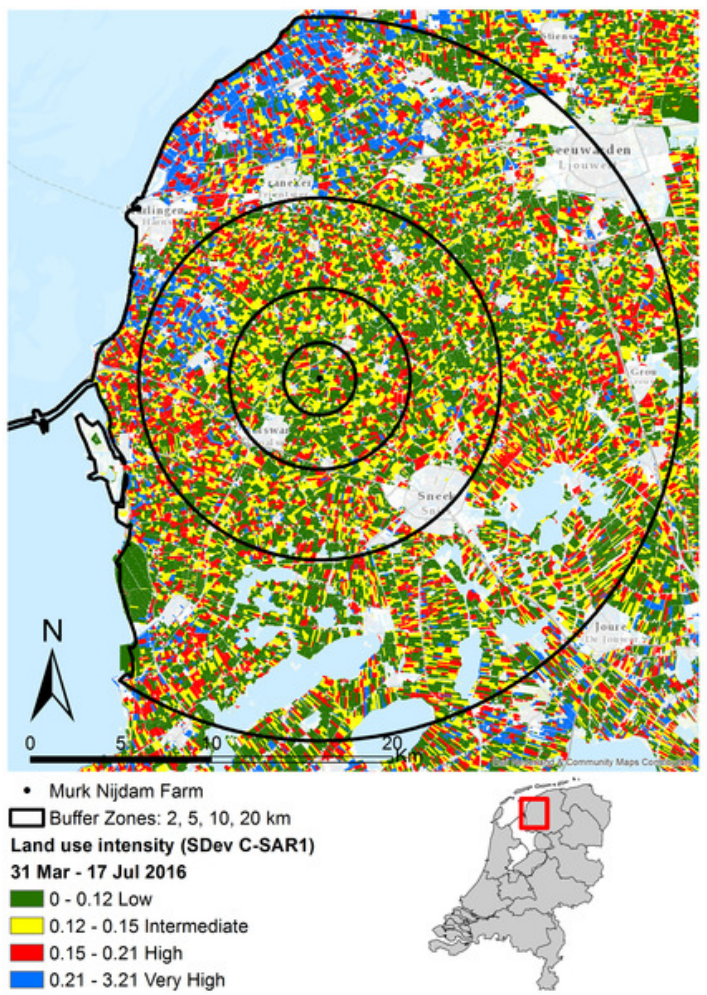

A

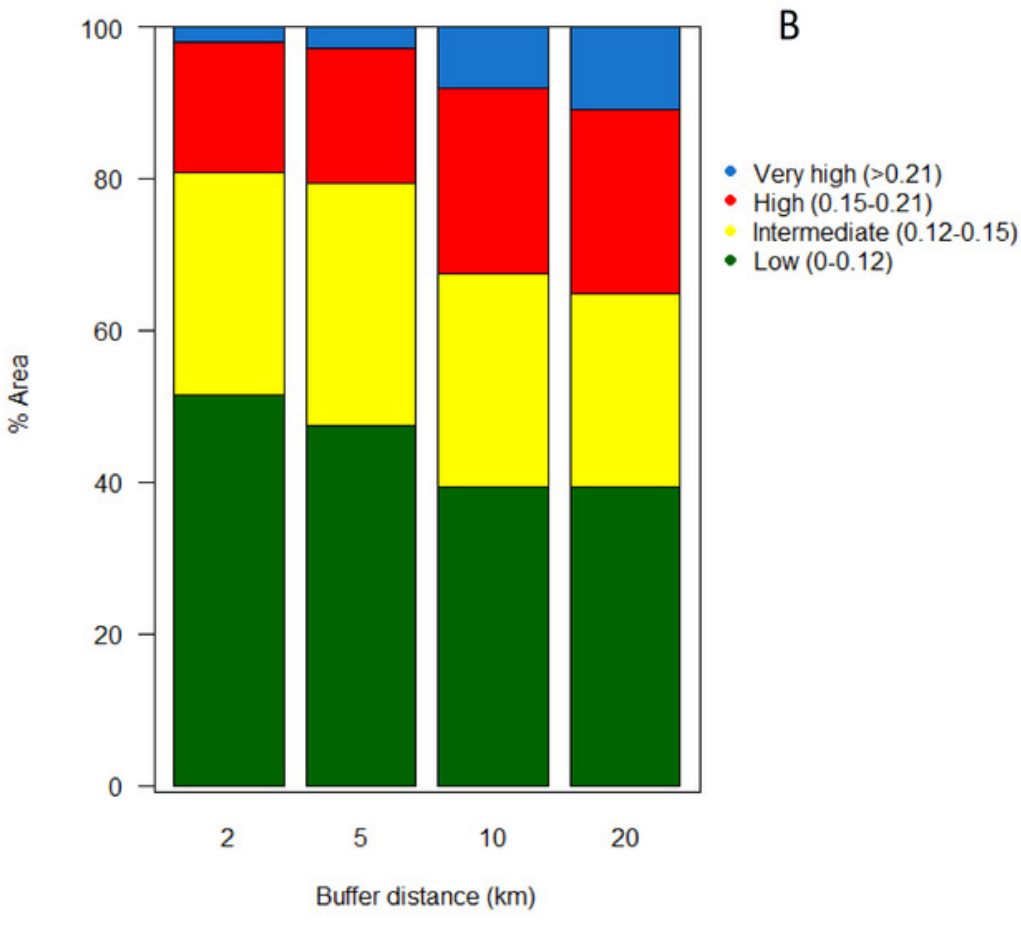


Figure 3

Soil temperature variation during the early season in day with irrigation $(A)$ and without irrigation (B) and during late season with irrigation (C) and without irrigation (D).

The solid red line follows the smoothed trend for the control (without added water) treatment, dark blue for the long-term (high water table) treatment and light blue the shortterm (irrigation) treatment, the shaded area in the respective colour represents \pm SD.

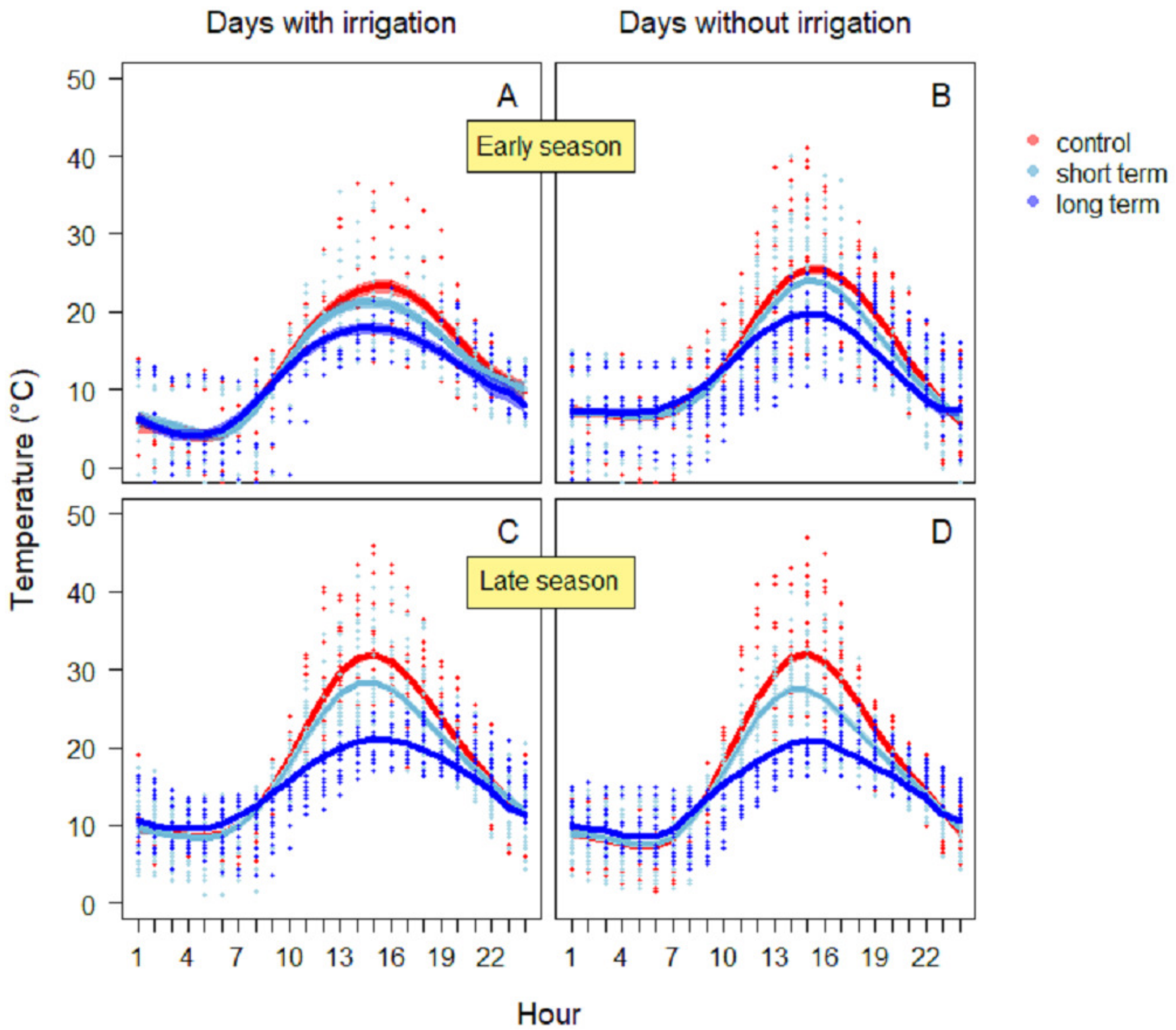


Figure 4

Soil characteristics and vegetation at the beginning (1 May), middle (17 May) and end of the season (8 June), under different treatments namely; control (without added water), long-term (high water table) and short-term (irrigation).

(A) soil moisture (\%), (B) soil resistance $\left(\mathrm{kg} / \mathrm{cm}^{2}\right)$ and $(\mathrm{C})$ vegetation height $(\mathrm{cm})$. 


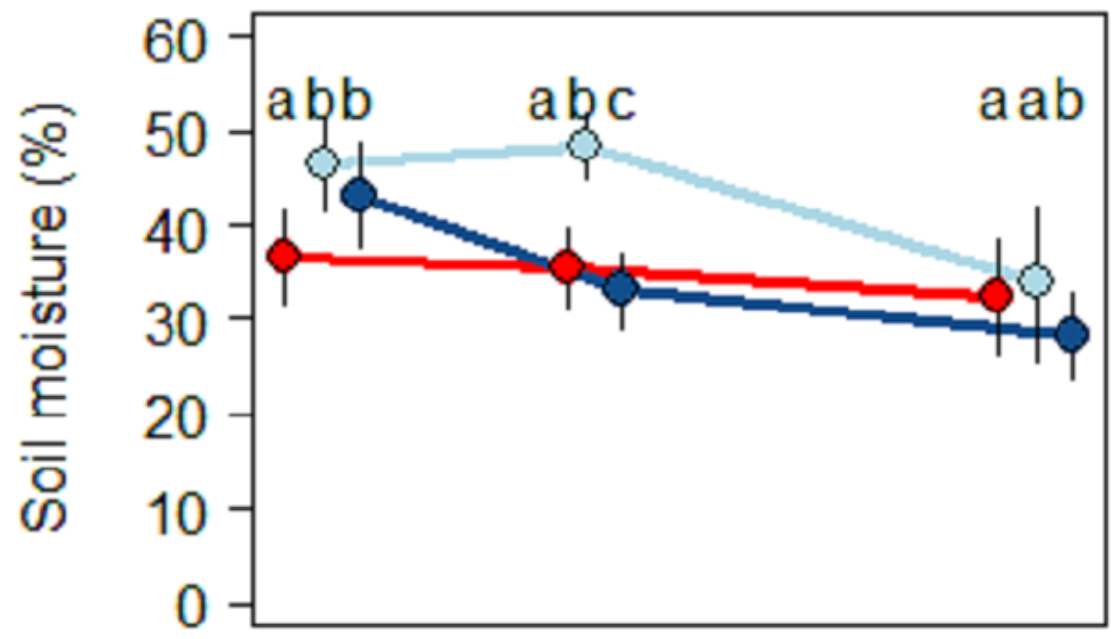

A

- control

- short term

- long term

त्र
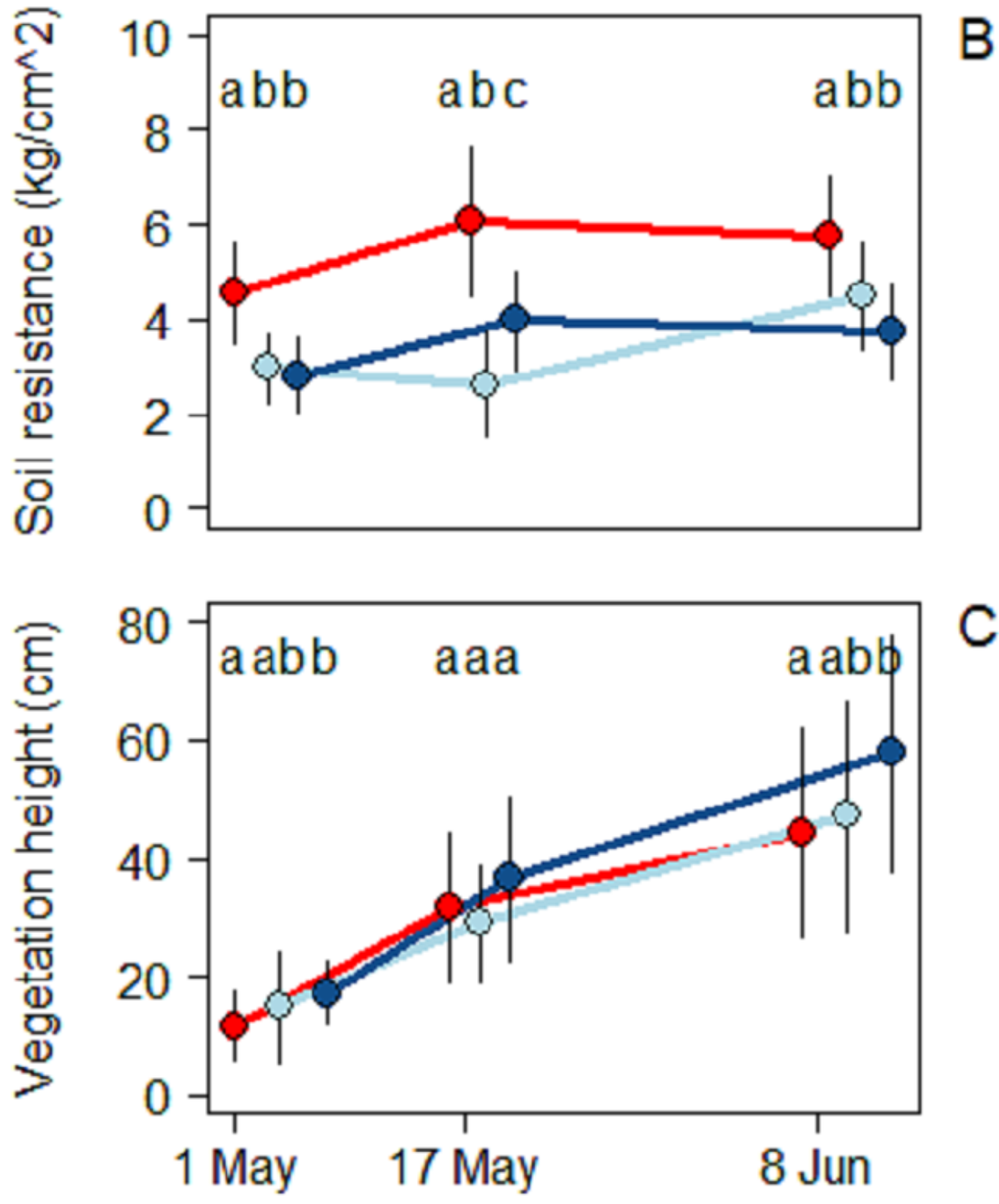

Date 


\section{Figure 5}

Biomass variation found in the sticky traps over the season.

(A) Diptera, (B) Lepidoptera, (C) Coleoptera, (D) Hemiptera and (E) Hymenoptera. The graphs are shown in order of decreasing biomass, note the different scales on the y axes. The solid red line follows the smoothed trend for the control (without added water) treatment, dark blue for the long-term (high water table) treatment and light blue the short-term (irrigation) treatment, the shaded area in the respective colour represents \pm SD. 


\section{Sticky traps}
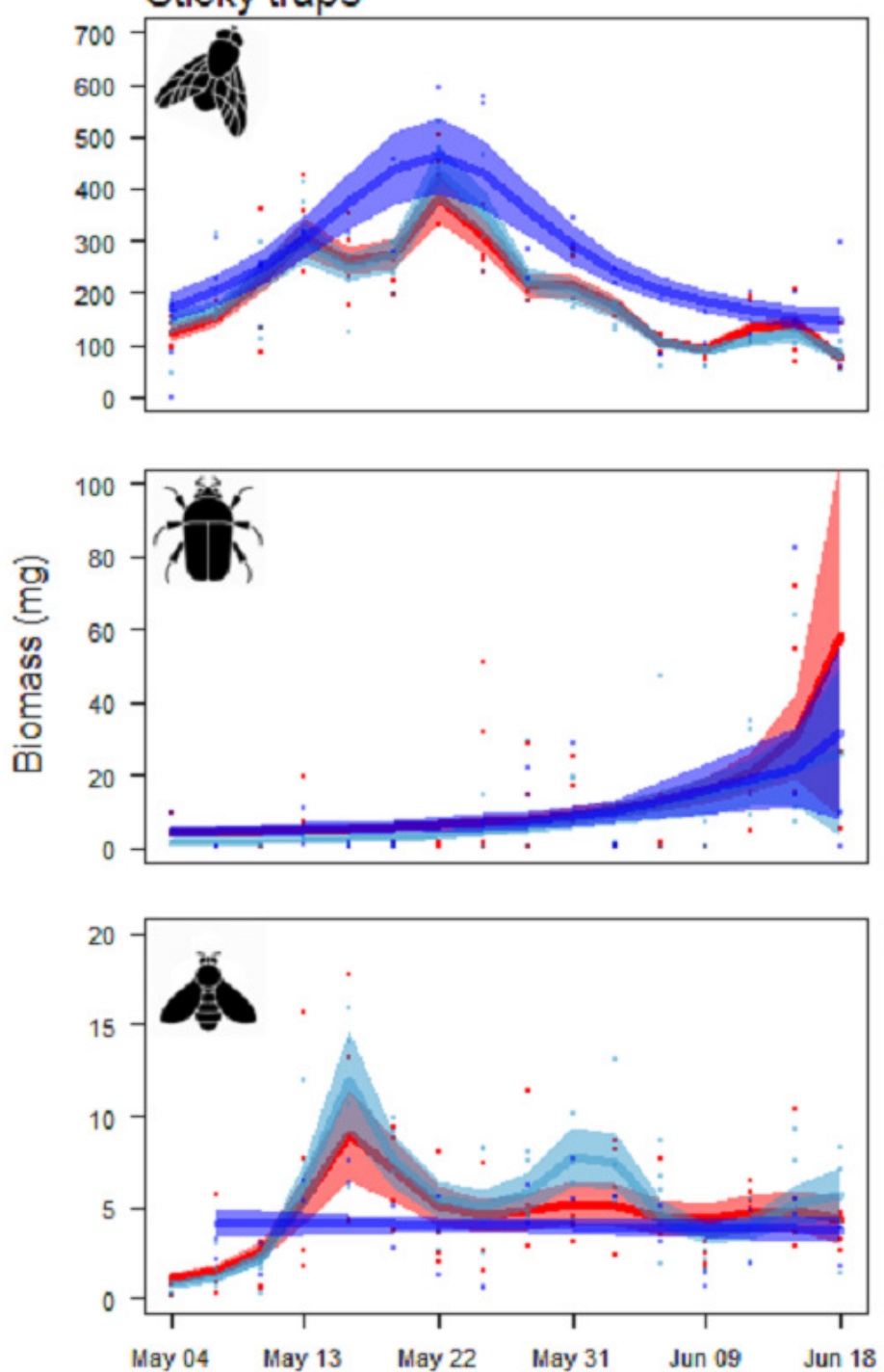

A
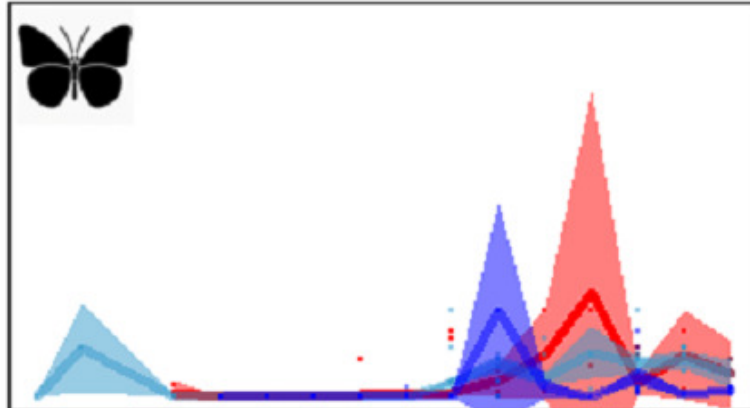

C

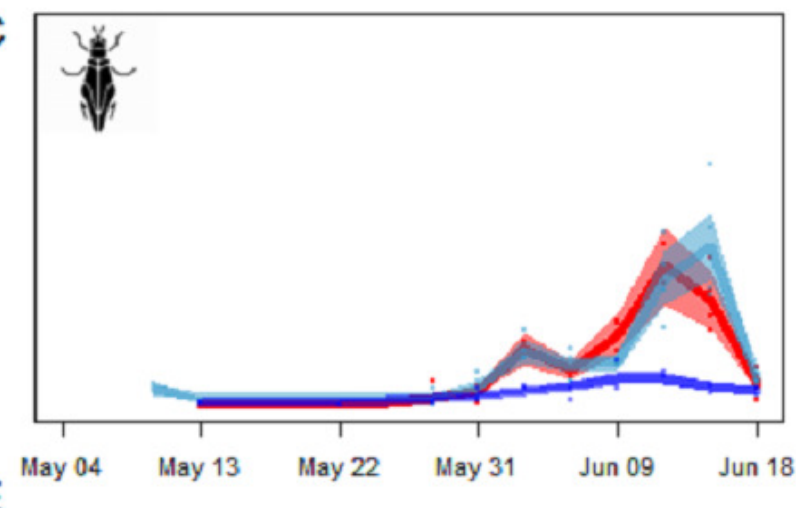

E

- control

- short term

- long term

\section{Date}




\section{Figure 6}

Size distribution of the arthropods during the season in the sticky traps.

In orange are individuals with length $\geq 4 \mathrm{~mm}$, yellow is for the $2-3 \mathrm{~mm}$ ones and in light blue $1 \mathrm{~mm}$.

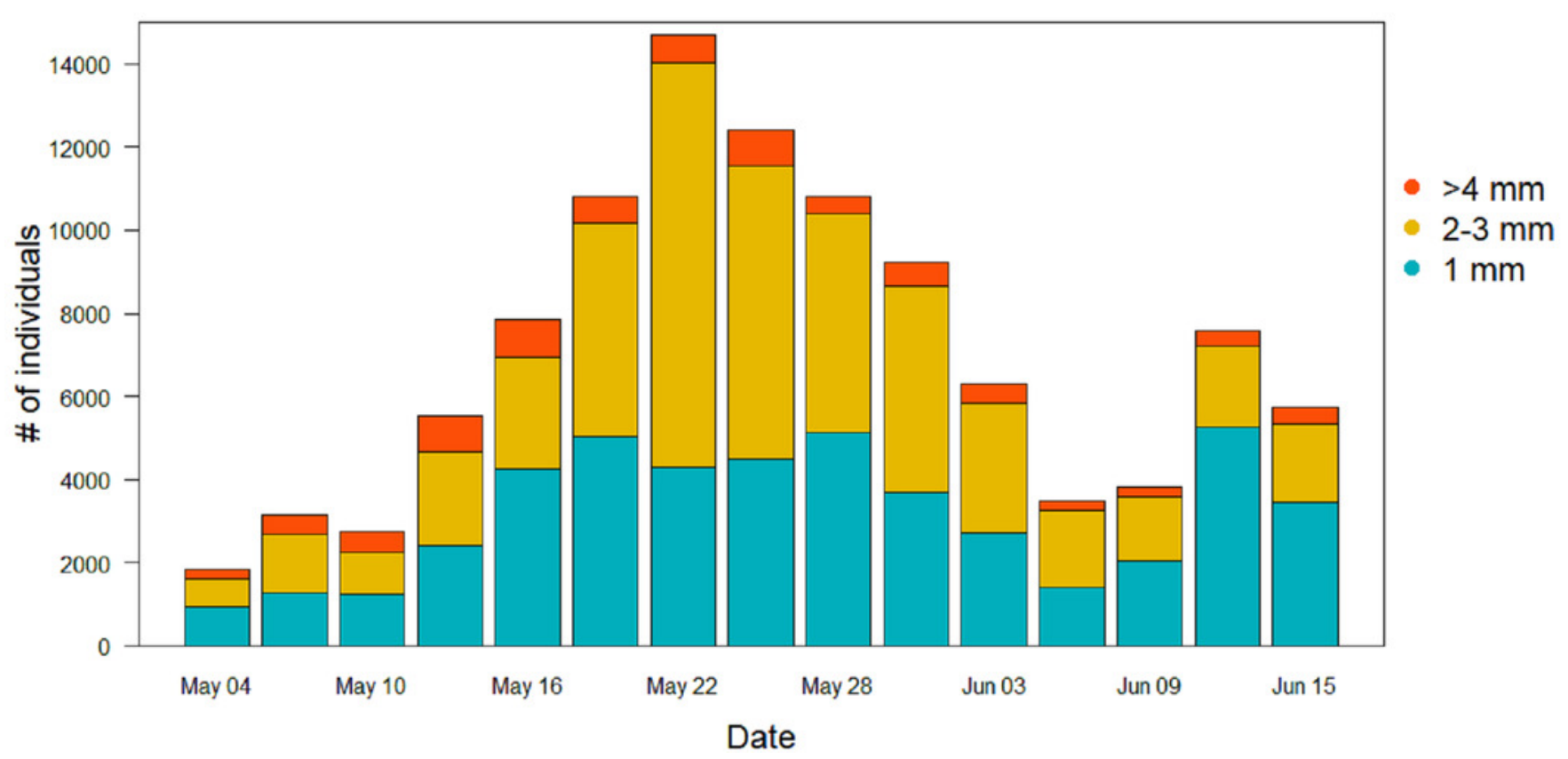


Figure 7

Biomass variation in found in the pitfall traps over the season.

(A) Coleoptera, (B) Aranaea, (C) Diptera and (D) Lepidoptera. The solid red line follows the smoothed trend for the control (without added water) treatment, dark blue for the long-term (high water table) treatment and light blue the short-term (irrigation) treatment, the shaded area in the respective colour represents \pm SD.

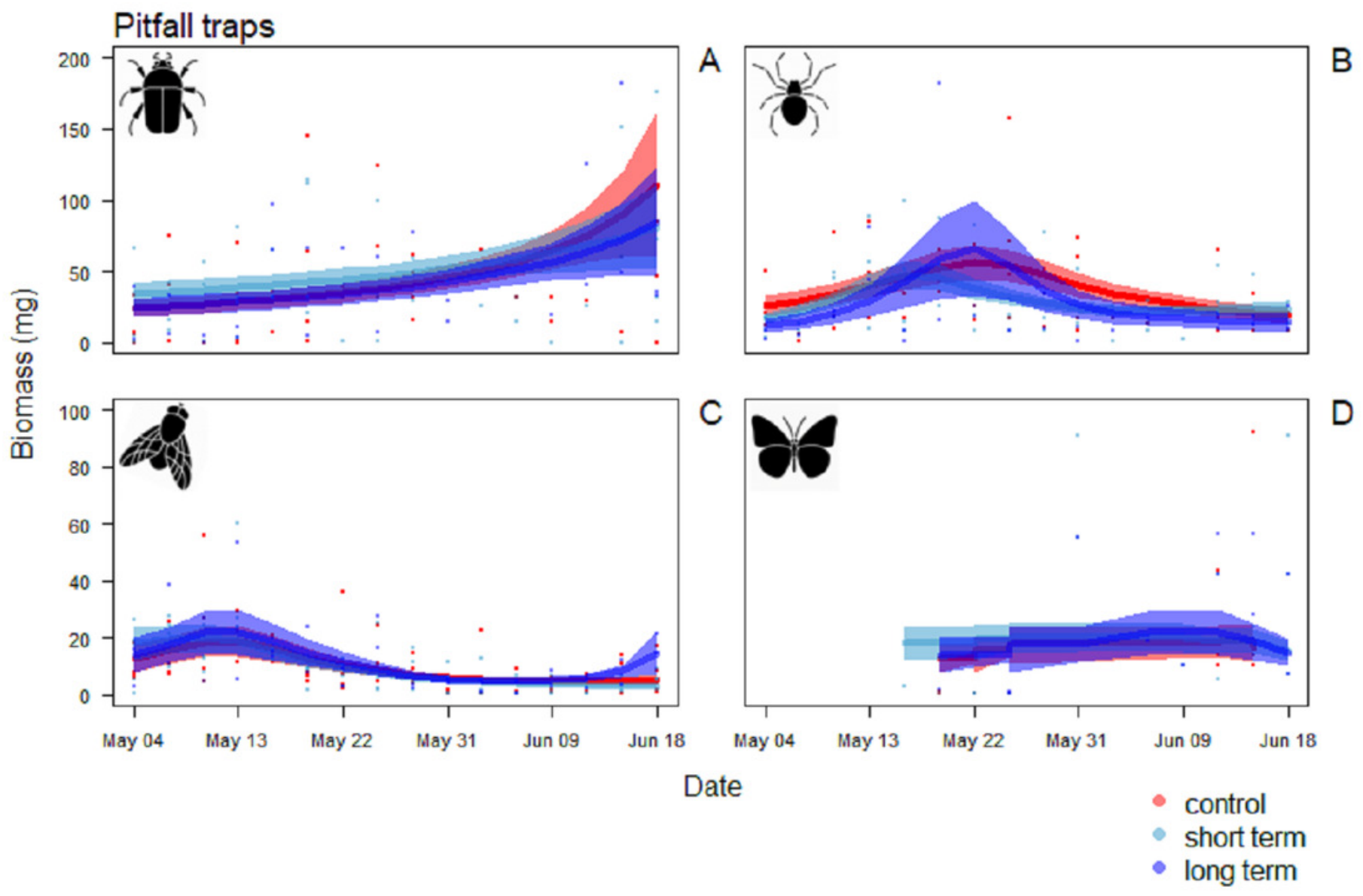




\section{Figure 8}

Size distribution of the arthropods during the season in the pitfall traps.

In orange are individuals with length $\geq 4 \mathrm{~mm}$, yellow is for the $2-3 \mathrm{~mm}$ ones and in light blue $1 \mathrm{~mm}$.

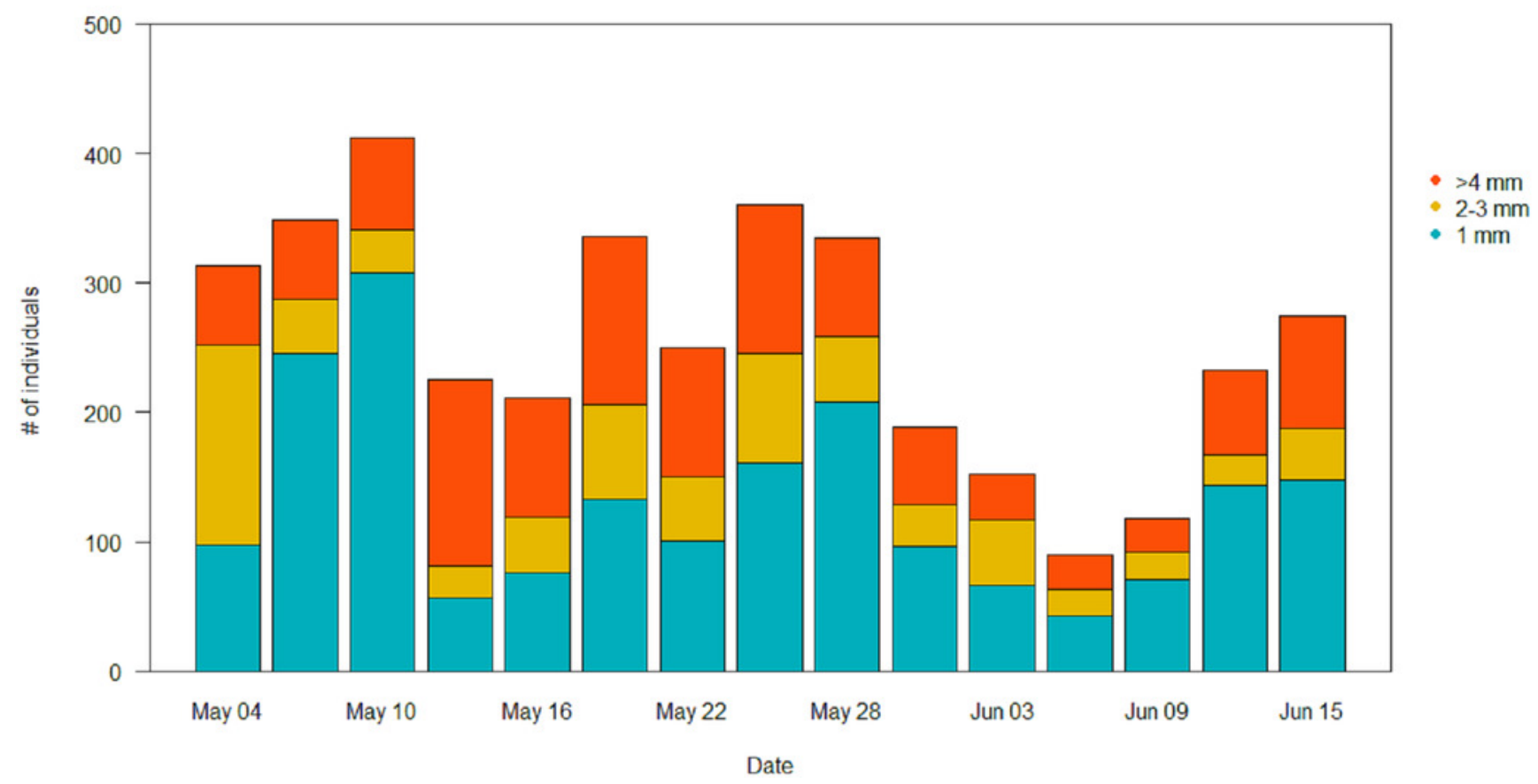




\section{Table $\mathbf{1}$ (on next page)}

Generalized Additive Model fit of soil temperature to treatment using time (hours) as smoothing term. 
1

\begin{tabular}{|c|c|c|c|c|c|c|c|c|}
\hline \multirow{2}{*}{$\begin{array}{c}\text { Temperature } \\
\text { Season }\end{array}$} & \multirow{2}{*}{$\begin{array}{c}\text { Days } \\
\text { with } \\
\text { irrigation }\end{array}$} & \multicolumn{2}{|l|}{ Treatment } & \multicolumn{3}{|l|}{ s(hour) } & \multirow[b]{2}{*}{$\mathrm{R}^{2}$} & \multirow[b]{2}{*}{$\begin{array}{l}\text { Deviance } \\
\text { explained }\end{array}$} \\
\hline & & F-value & $p$-value & F- value & Edf & $p$-value & & \\
\hline \multirow[t]{2}{*}{ Early } & Yes & $F_{2,684}=8.54$ & $<0.001$ & 129.3 & 7.01 & $<0.001$ & 0.62 & $62.7 \%$ \\
\hline & No & $F_{2,1728}=19.21$ & $<0.001$ & 366.2 & 7.14 & $<0.001$ & 0.64 & $64 \%$ \\
\hline \multirow[t]{2}{*}{ Late } & Yes & $F_{2,1512}=59.45$ & $<0.001$ & 457.9 & 7.04 & $<0.001$ & 0.72 & $72 \%$ \\
\hline & No & $F_{2,1512}=59.76$ & $<0.001$ & 497.7 & 7.64 & $<0.001$ & 0.74 & $74.5 \%$ \\
\hline
\end{tabular}

2 Edf refers to the effective degrees of freedom for the smoothing spline.

3

4 


\section{Table 2 (on next page)}

Generalized Additive Models fit of arthropod biomass to treatment using date as smoothing term for sticky traps. 
1

\begin{tabular}{|c|c|c|c|c|c|c|c|}
\hline \multirow{2}{*}{$\begin{array}{l}\text { Sticky traps } \\
\text { Order }\end{array}$} & \multicolumn{2}{|l|}{ Treatment } & \multicolumn{3}{|l|}{ s(date) } & \multirow[b]{2}{*}{$\mathrm{R}^{2}$} & \multirow{2}{*}{$\begin{array}{l}\text { Deviance } \\
\text { explainec }\end{array}$} \\
\hline & F-value & $p$-value & F-value & Edf & $p$-value & & \\
\hline Diptera & $F_{2,160}=10.57$ & $<0.001$ & 29.23 & 8.76 & $<0.001$ & 0.76 & $56.9 \%$ \\
\hline Lepidoptera & $F_{2,160}=0.27$ & 0.77 & 1.65 & 0.38 & $<0.001$ & 0.38 & $56.1 \%$ \\
\hline Coleoptera & $F_{2,160}=0.28$ & 0.75 & 4.4 & 8.79 & $<0.001$ & 0.41 & $38.1 \%$ \\
\hline Hemiptera & $F_{2,160}=9.81$ & $<0.001$ & 14.92 & 7.66 & $<0.001$ & 0.81 & $80.3 \%$ \\
\hline Hymenoptera & $F_{2,160}=2.65$ & $<0.1$ & 8.09 & 7.49 & $<0.001$ & 0.42 & $41.2 \%$ \\
\hline
\end{tabular}

2 Edf refers to the effective degrees of freedom for the smoothing spline 


\section{Table 3(on next page)}

Summary of the log ratio differences comparing the cumulative arthropod biomass of the control treatment (no water added) $(N=4)$ to the irrigation treatment $(\mathrm{N}=4)$ and near water treatment $(N=2)$. 


\begin{tabular}{|c|c|c|c|c|}
\hline \multirow[b]{2}{*}{ Replicates } & \multicolumn{2}{|c|}{ Sticky Traps } & \multicolumn{2}{|c|}{ Pitfall Traps } \\
\hline & Short-term & Long-term & Short-term & Long-term \\
\hline 1 & 0.151 & 0.289 & 0.456 & 0.481 \\
\hline 2 & 0.124 & 0.106 & 0.223 & -0.018 \\
\hline 3 & -0.032 & - & -0.043 & - \\
\hline 4 & -0.059 & - & -0.276 & - \\
\hline Iverage & 0.046 & 0.197 & 0.090 & 0.232 \\
\hline
\end{tabular}

1 


\section{Table 4 (on next page)}

Generalized Additive Models fit of arthropod biomass to treatment using date as smoothing term for pitfall traps. 


\begin{tabular}{|c|c|c|c|c|c|c|c|}
\hline \multirow{2}{*}{$\begin{array}{l}\text { Pitfall traps } \\
\text { Order }\end{array}$} & \multicolumn{2}{|l|}{ Treatment } & \multicolumn{3}{|l|}{ s(date) } & \multirow[b]{2}{*}{$\mathrm{R}^{2}$} & \multirow{2}{*}{$\begin{array}{l}\text { Deviance } \\
\text { explained }\end{array}$} \\
\hline & F-value & $p$-value & F-value & Edf & $p$-value & & \\
\hline Coleoptera & $F_{2,160}=0.15$ & 0.86 & 14.55 & 1 & $<0.001$ & 0.08 & $7.96 \%$ \\
\hline Aranaea & $F_{2,160}=0.87$ & 0.42 & 5.35 & 3.65 & $<0.001$ & 0.13 & $21 \%$ \\
\hline Diptera & $F_{2,160}=0.38$ & 0.68 & 8.54 & 5.50 & $<0.001$ & 0.35 & $30.5 \%$ \\
\hline Lepidoptera & $F_{2,160}=0.20$ & 0.82 & 4.88 & 7.70 & $<0.001$ & 0.45 & $86.6 \%$ \\
\hline
\end{tabular}

1 Edf refers to the effective degrees of freedom for the smoothing spline.

2

3 